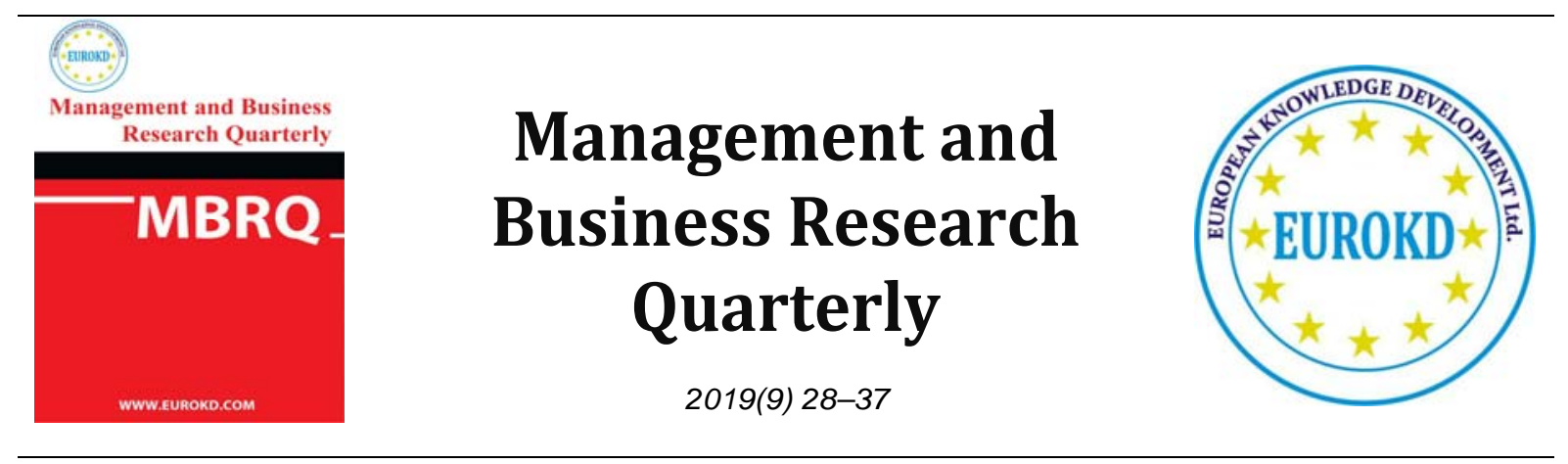

\title{
Case Study of Pt Astra International Tbk Corporate Social Responsibility Communication through Company Website and Annual Report
}

\author{
Wuryan Andayani \\ Brawijaya University Malang, Indonesia
}

Received 17 April 2019 Accepted 26 May 2019

\begin{abstract}
The corporate social responsibility of PT Astra International Tbk through the company's website. This research is also based on subjective research using case study research methods. The object of this research is the website of PT Astra International Tbk, namely www.astra.co.id. The researcher chose PT Astra International as a case study intended to analyze the company's website which contained information about CSR. The researcher used the company's website documentation technique. Overall, PT Astra International Tbk communicates CSR to meet company requirements in accordance with applicable regulations and policies. Statement of content for information communicated about program implementation and results. In addition, the priority built by the company through communicating CSR through packaging information to create a good impression is very important. The researcher concludes that basically, substantive support that is balanced with the company's performance, behavior and communication in implementing CSR is very important.
\end{abstract}

Keywords: Corporate Social Responsibility, Website, Company Reputation

\section{Introduction}

Law No. 25 of 2007 Article 15, Article 17 and Article 34 concerning Capital Investment, regulate the obligation for companies to implement CSR. Corporate Social Responsibility (CSR) is a form of corporate social responsibility to the community around the company. CSR has developed in Indonesia since the $1980 \mathrm{~s}$, used to maintain the survival of the company by paying attention to the 
company's internal and external relations. Companies that carry out CSR programs will get a positive impact on the survival of the company.

The company, PT Astra International Tbk must manage the company itself well so that it maintains its survival. The company must also be able to maintain its reputation because it will affect the survival of the company. CSR is one of the strategies carried out by the company in order to get a good assessment from stakeholders (interested parties).

Du et al., (2012: 415) states that stakeholders have high expectations for the company to implement CSR. Bruhn and Hansen (2012) state that companies are required to change the company's attention from the value of shareholders to maximize profits into stakeholder values to balance 3P (people, planet and profit). The company must enter the company's mission and slogan to increase the company's credibility in implementing CSR. The higher the company has integrity towards CSR, the more stakeholders will view CSR as part of corporate identity ((Du et al. 2007).

Great attention has been focused over the past few years on environmental information (Branco and Rodrigues, 2006). The study of environmental information is focused on CSR disclosure. The Annual Report is a tool used by companies to communicate with their stakeholders. Currently the internet is also an important medium for disclosing information. They tested the information on CSR disclosures on the internet of Banks in Portugal in 2004 and compared them with the 2003 Annual Report as a medium of disclosure. Using content analysis, disclosure of CSR is classified into themes (environment, human resources, products and customers and community involvement). The findings indicate that banks with higher visibility towards customers will give higher attention to the improvement of the company through its image of CSR disclosure information. The findings show that the legitimacy theory can explain information on CSR disclosure in banks in Portugal.

One of the company's strategies to get a good reputation is by implementing CSR. The company's reputation is the result of stakeholder evaluations of the company (Coombs, 2007). A good communication channel owned by a company can be a communication channel about a company's CSR activities. Furthermore, Nwagbara and Reid (2013) stated that CSR must be communicated with various stakeholders so that the company can build a reputation through corporate communication channels. The company communicates CSR through corporate websites in the current era (Parker et al., 2010).

\section{Literature Review}

\section{Definition of Corporate Social Responsibility (CSR)}

Gray et. al. (1996) defines CSR as a process of corporate communication with the community and the surrounding environment. CSR communication will affect the company's economic actions. The CSR communication process reflects the social and environmental actions around the company. Such actions will affect the economic actions of the company and provide influences related to employees, community involvement, attention to the environment and other ethical actions.

Benabou and Tirole (2010); Mc Williams and Siegel (2001) state that companies that make profits, should provide benefits (CSR activities) to the community. Companies must voluntarily do 
and comply with regulations and contracts legally. The CSR includes environmentally friendly actions, good employees, and ethical actions related to the community.

Parker (2010) states that CSR is a voluntary action taken by the company by accommodating stakeholder expectations and interacting with stakeholders. This shows that corporate communication with stakeholders is very important. Communication of CSR can build the company's reputation. GRI (2017) states that companies need to communicate sustainability reports strategically and comprehensively. The sustainability report can be used to communicate the company's success story in managing its economic, social and environmental aspects. Sustainability reports can be communicated through communication media such as print and electronic advertisements, talk shows, infographics, short videos, press conferences, seminars and company websites.

\section{CSR Communication Channels}

Communication of CSR is based on the principle of transparency in accordance with GRI. GRI (2011) states that there are 3 (three) components that are communicated to stakeholders, namely (1). Strategy and Profile that reveals about strategy, profile and corporate governance; (2). Management Approach that reveals how the company provides an understanding of company performance; (3). Performance Indicators reveal indicators of economic, environmental and social performance of the company.

The following is an overview of GRI (2011) standard disclosures:

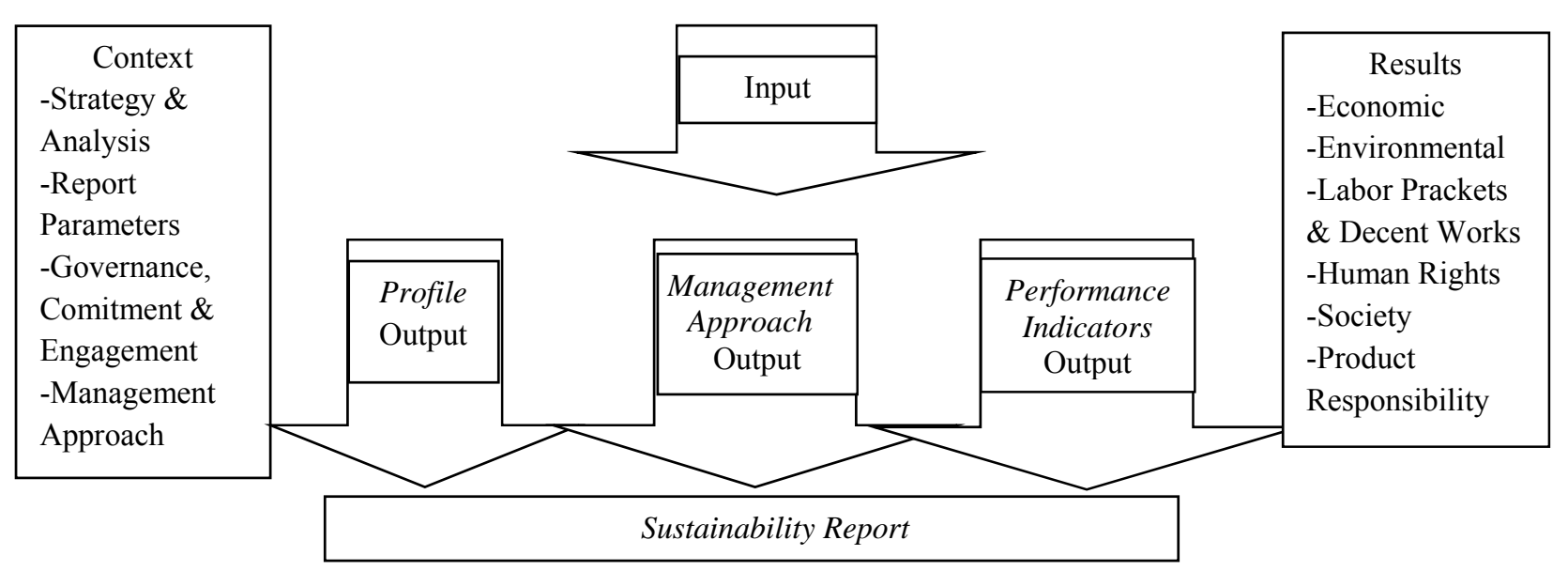

Figure 1. Disclosure Standards

Source: GRI 2011

Communication channels for CSR activities carried out by companies can be through various communication media such as print and electronic advertisements, talk shows, infographics, short videos, press conferences, seminars and company websites. Du et al (2012) stated that company websites are easily accessible communication channels that provide comprehensive information about CSR. 
The research question: Does PT Astra International Tbk provide CSR information to the stakeholder through website and Annual Report?

\section{Research Methods}

This research is a descriptive qualitative study. This research also bases on subjective researchers using case study research methods. The object of this research is the website of PT Astra International Tbk, namely www.astra.co.id and Annual Report. The researcher chose PT Astra International as a case study because it aimed to analyze the company's website that contained information about CSR. The researcher used the company's website documentation technique.

\section{Research Result}

\section{Astra Profile}

PT Astra was established in 1957, is one of the largest companies in Indonesia. PT Astra has 7 (seven) business lines and houses 210 subsidiaries with 210,000 employees throughout Indonesia. PT Astra has aspirations of becoming prosperous with the nation and working to adhere to the Catur Dharma guidelines. The goal is manifested as the Strategic Triple-P Roadmap, which is to balance business growth with the development of human resources and contribute to society.

The Catur Dharma philosophy includes (1). Being a property that is beneficial to the nation and state; (2). Providing the best service to customers; (3). Respect individuals and foster cooperation; (4). Always trying to achieve the best. Since 2010 Astra has set the Goal of 2020 namely "Pride of the Nation" as outlined in the Triple-P Roadmap initiative. This strategy includes (1). Portfolio Roadmap to increase value for shareholders, (2). People Roadmap in order to build competent and competitive Astra Persons, and (3). Public Contribution Roadmap, namely providing benefits through environmental management, occupational safety and health in all Astra installations, and realizing social responsibility to the community.

\section{Management Approach}

Management Approach that reveals how the company provides an understanding of company performance. PT Astra International Tbk approaches management as follows:

1. Best Products and Services:

PT Astra International Tbk provides the best service to customers. PT Astra has products such as Astra Life, Astra Insurance, Astra Toyota Agya and Astra Daihatsu Ayla, Astra Toyota Calya and Astra Daihatsu Sigra, GS Astra, TRAC, Menara Astra, ASPIRA, Shell Helix Astra and so on. The addition of Astra's name is a guarantee of the quality of products and services to consumers, because it has a brand equity and is well received in Indonesia.

PT Astra maintains the company's reputation and has a strong brand value with various efforts to ensure the best quality standards in safeguarding customer rights. Astra has a commitment to provide products and services that are applied along the sales value chain including:

a. Provision of products that are safe for community use and meet applicable standards and regulations in the market country. 
b. Provide clear product information on how to use, maintain, information on parts, disposal and post-sales services so that each Astra product can be used in a safe and correct manner according to its purpose.

c. Providing understanding to prospective customers and customers, regarding matters relating to products through Astra service channels.

Astra provides comprehensive services at all times to consumers so that consumer loyalty increases. Consumers can get services ranging from consultations, loan offers, insurance, to emergency services from Astra's product solutions and service centers. Furthermore, communication services to customers through customer service, hotline service and e-mail on the company's website are Astra's steps to establish good relations with customers. Every complaint from the customer is always resolved in accordance with the Service Level Agreement at the earliest in one day and no later than one week after the customer complaint is received.

\section{PT Astra International Tbk and Development}

PT Astra continues to provide added value in development through the supply chain, employment absorption, foreign exchange proceeds from exports, and sustainable social contribution programs carried out by the Astra Group and become a social investment for sustainable development.

Astra supports development programs by conducting various programs such as developing and empowering micro, small and medium enterprises (MSMEs) throughout Indonesia. Empowerment is carried out on various MSMEs such as fabrication, workshops and so on, especially in the business ecosystem. The development began with fostering MSMEs in order to become better businesses and become partners of the Astra Group.

\section{Communication, CSR and Corporate Security Policy}

The field of environment, occupational safety and health and social responsibility include:

A. Environment, Occupational Safety and Health includes

1. Implementation of the Astra Green Company (AGC) with a minimum green rating and blue rating for the manufacturing, mining and plantation categories.

2. Comply with and implement regulations and / or standards in the field of occupational health and safety (K3) and compliance with PROPER regulations (blue).

3. Implementation of the Behavior Based Safety (BBS) program in all Astra Group companies by focusing on reducing risk behavior (at risk behavior).

4. Paying attention to occupational health aspects through the movement of healthy living communities (GERMAS) and prevention of Narcotics hazards in the work environment.

5. Efficiency of natural resources, energy and a reduction in greenhouse gases of at least $2.5 \%$ per product unit compared to 2016 through the implementation of Astra Green Energy with a focus on the Sustainable Consumption and Production program.

B. Social Responsibility

The social responsibility of PT Astra International Tbk includes:

1. Implementation of the Astra Friendly Company (AFC) with a minimum target of 4 stars. 
2. Ensure the spectrum of the spread of implementation of Astra CSR programs in each Province.

3. The CSR program carried out needs to be optimized through cooperation with various parties such as: local governments, academics, associations, social communities and other institutions so that the impact of the program is broader.

4. Development of the 4 (four) innovation pillars of Astra's CSR programs that are in line with the results of social mapping, the impact of business processes and the Public Contribution Roadmap 2020 with a focus on: (a). Pillars of Education, coaching and quality improvement, namely:

I. Early Childhood Education through "SAPA Smile" (PAUD Astra's best friend), primary and secondary education both through fostering Adiwiyata schools and improving the quality of vocational education.

II. Development of the Indonesian program Ayo Aman Berlalu Lintas (IAABL) through the establishment of IAABL pioneers in each company both internally and externally. The pillar of entrepreneurship, empowerment of the community economy through enhancing entrepreneurial skills based on creative economy, marketing support, strengthening the forum "I CAN" (Association of Astra Small Business Actors) which focuses on the community and people with disabilities.

III. Environmental pillars, the development of the Astra Forest as a conservation area (green open space) and sustainable integrated biodiversity protection.

IV. Health pillar, implementation of the "Astra KIRANA" program (Maternal, Youth and Child Health) with the aim of improving the health status of mothers, adolescents and children through the promotion of clean and healthy lifestyles, improving nutrition, family planning by strengthening Astra health cadres. The four pillars can be implemented through the establishment of Astra's (Clean, Healthy, Smart and Productive) Village in each region.

The K3 management and the environment in Astra's workplace always strives to minimize the negative impact of business on the environment, by creating a safe and healthy work environment. Astra is also committed to social responsibility to manage environmentally friendly business activities, according to Astra's vision to be a company that has social responsibility and is environmentally friendly. To support the K3 objectives and environmental management and ensure continual improvement, the Astra group adopts and implements the K3 Management System certification, ISO 14001, OHSAS 18001 and ISO 9001 and Management Systems in other LK3 fields.

Zero Accident Astra is aimed at realizing social responsibility by managing Occupational Safety and Health (K3) and the Environment in the workplace to provide protection for employees. With protection for employees, it is expected that employees can work comfortably and safely so that productivity can increase. Astra is also committed to realizing the Zero Workplace Accident target. This target aims to improve the safety of employees, prevent work accidents, and get sick from work, while providing security to all employees and everyone in the company. 
Astra's K3 implementation is implemented through work guidelines that regulate OHS awareness and competence, routine safety talk, program contractor safety management system (CSMS) and behavior based safety. This K3 implementation emphasizes data recording, analysis and anticipation and behavior changes that are consistently implemented in the Astra Group.

Social and environmental responsibility in principle, wherever the Astra installation is located must provide benefits to the community and the surrounding environment. The social responsibility is in accordance with the first point of the philosophy of Catur Dharma Astra, namely "Being Owned that Benefits the Nation and State". Through the Public Contribution Roadmap, social and environmental benefits are realized through 4 (four) Astra CSR pillars, with the aim of empowering and building community independence so that they can actively participate in driving the local economy and improving Indonesia's welfare.

Astra's Astra Friendly Company has used the Astra Friendly Company (AFC) which was developed as a guideline for the Astra Group to implement social contributions (CSR). With this guideline, each Astra installation can implement a CSR work program systematically by considering the fulfillment of stakeholder rights. The AFC is prepared with references from various national or international standards or guidelines. The AFC criteria consist of management systems, namely value, mindset, and behavior, implementation of Astra's four-pillar CSR program, public perception and donations. The implementation of AFC is carried out by conducting an AFC audit on the relevant Astra installation.

\section{Performance Indicators}

Performance Indicators reveal indicators of economic, environmental and social performance of the company.

\section{Astra Business Performance 2017}

Over the past few years the company has made new milestones by exploring different opportunities compared to a decade ago. In 2017, Astra inaugurates Menara Astra and Anandamaya Residences, which are the first Astra property projects. Through its business lines, Astra also participates in building Indonesia's infrastructure through its subsidiary Astra Tol Nusantara (formerly called Astratel) which operates in several infrastructure sectors. Until now Astra Tol Nusantara already has a toll road of $353.4 \mathrm{~km}$, from the overall target of $500 \mathrm{~km}$ in 2020.

\section{Portofolio Roadmap}

In 2017 almost all business lines of PT Astra International Tbk experienced growth. Consolidated net income in 2017 rose to 14\%, which is around Rp206.1 trillion compared to 2016 which reached Rp.181.1 trillion. Net income for 2017 increased by 25\% from IDR 15.2 trillion compared to 2016, around IDR 18.9 trillion. In 2017, although competition in the car market continued to increase, the Astra Group benefited from the sustained rise in commodity prices that supported the performance of heavy equipment and mining and agribusiness. Meanwhile, the financial segment again contributed positively to the Group. 
Managing Suppliers, Managing Sustainability. In protecting business sustainability and in accordance with the commitment to always provide the best products and services, Astra manages the quality of suppliers that provide goods and services for the company. Astra has a supplier management policy through a selection and evaluation process to protect business interests and the rights of work partners, by upholding the principle of mutual trust and in line with the values of QCDSM (Quality, Cost, Delivery, Safety, Morale).

During the period of cooperation, there is guidance, monitoring and evaluation of work partners conducted periodically to measure their performance. This measurement is based on indicators of quality, cost, delivery, labor practices, fulfillment of human rights, management indicators and environmental performance as well as occupational safety and health management.

\section{Evaluation and Performance Management}

Performance appraisal is carried out for each activity carried out objectively and periodically every six months based on achieving key performance indicators (KPI) that have been agreed between the company and employees at the beginning of the year and implementing the PDCA concept (plan-do-checkaction).

Especially for leaders who already have staff, the assessment process also sees its ability to manage the team (people management). The tiered evaluation is carried out at a minimum of 2 levels of employee supervisors while feedback is given by superiors in the form of direction, guidance and evaluation. Increasing Engagement One of Astra's priorities in 2017 is how employees have a strong bond with the company where they work.

\section{Career Certainty}

In line with the implementation of Astra People Roadmap, "dual career ladder" is developed, namely the generalist and specialist paths, from the previous one there was only one career gap in Astra. With this system, the company has one of the most important infrastructures in the development of Astra's own natural products and services.

With the dual career ladder, specialists get significant added value and high motivation to continue to contribute to the Astra Group company. Employee career paths are determined based on performance evaluation, where the promotion process can be carried out at the beginning of the year or mid-year. The aspect that is observed in the promotion is the achievement of performance, the readiness of candidates to occupy a higher position, both in terms of technical competence or the behavior they have.

\section{Astra Green Company (AGC)}

Astra has developed the Astra Green Company (AGC) as an LK3 management system to monitor the achievement of the company's performance in fulfilling various K3 and environmental management requirements in the workplace, including national and international regulations and standards. 
Performance measurement related to LK3 is carried out using a series of assessment criteria to meet the green strategy criteria, process, product, employee, achievement of critical points and compliance with regulations. Evaluations are carried out in stages through the Corporate Assessment, Group Assessment and Self Assessment, to produce achievement ratings in the categories of gold, green, blue, red and black, respectively as the highest to lowest achievements.

In 2017, Astra targets to achieve a minimum rating of Blue for the manufacturing, mining and plantation categories and rank Green for other categories. The assessment was carried out on 529 Astra Group installations that were eligible for audit and $73.72 \%$ reaching Green and Gold ratings.

\section{Company Performance Rating Program}

The Corporate Performance Rating Program (PROPER) is a Government program through the Ministry of Environment and Forestry that assesses environmental management based on compliance and beyond compliance efforts. For Astra Group installations that are included in PROPER, a minimum target is Blue Rating.

In 2017, there were 52 Astra installations included in the subject of the 2016-2017 PROPER implementation, 41 of which obtained Blue Ratings and 11 received Green Ratings. None of Astra's installations have Red and Black ratings. Implementation of the Sustainable Consumption and Production The Astra Group implements Sustainable Consumption and Production (SCP) in the production and operational processes. In 2017, Astra set a target of decreasing the intensity of natural resource use by $2.5 \%$ per product unit compared to the previous year.

Astra continuously makes improvements and innovations to improve the efficiency and optimization of the use of materials and natural resources and energy and reduce waste by adopting a Quality Control approach.

\section{Conclusions and Limitations Conclusions}

The company website of PT Astra International Tbk is easily accessible and sustainability report documents are archived on the company's website and are presented in two languages, namely Indonesian and English. In terms of interactivity, the company's website can be said to be noninteractive because there is no two-way communication space available that allows interaction and exchange of information between the company and stakeholders, and between stakeholders. Information on the company's website can be said to be in-depth and comprehensive with the establishment of a company website that specifically contains CSR information.

The results of the study show that the contents of the message communicated by PT Astra International Tbk through the company's website related to CSR have not communicated all aspects that need to be communicated which are recommended by GRI which are principled on aspects of transparency. Companies tend to communicate information about program implementation and program results in the form of program success. However, the impact of company operations and the CSR design process which are aspects that need to be communicated in accordance with the principle of transparency is not communicated. 
Overall, PT Astra International Tbk communicates CSR to meet company obligations in accordance with applicable regulations and policies. This statement is indicated by the tendency of information communicated about the implementation and results of the program. In addition, the reputation built by the company through communicating CSR is made through giving information to create a good impression. The researcher concludes that basically, substantive support that is balanced with the company's performance, behavior and communication in implementing CSR is very important.

\section{Limitations}

This study has limitations in the scope of research that is limited to PT Astra International Tbk. Researchers suggest further research in order to enrich research on communicating CSR through corporate websites with different research objects. The researcher also suggested further research to conduct a comparative study on communicating CSR through the company's website.

\section{References}

Benabou, R \& Tirole, J. 2010. Individual and Corporate Social Responsibility. Economica, 77, 305, 1-19

Branco, Manuel Castelo; Lu Cia Lima Rodrigues. 2006. Communication of corporate social responsibility by Portuguese Banks A Legitimacy Theory Perspective. The current issue journal at www.emeraldinsight.com/1356-3289.htm. Diakses 17 September 2018.

Bruhn, S., dan Hansen. 2012. Corporate social responsibility: a case study of Starbuck's CSR communication through its corporate website. Bachelor. Marketing and Management Communication. Tersedia di: < http://pure.au.dk/portal/files/45282206/BA_Thesis.pdf. Diakses tanggal 18 September 2018

Coombs, W. 2007. Ongoing Crisis Communication: Planning, Managing, and Responding. Second Edition. California: Sage Publication

Corporate Communications: An International Journal Vol. 11 No. 3, 2006 pp. 232-248 q Emerald Group Publishing Limited 13563289 DOI 10.1108/13563280610680821

Du, S., Bhattacharya, C. B., \& Sen, S. 2007. Reaping relational rewards from corporate social responsibility: The role of competitive positioning. International Journal of Research in Marketing, 24(3), 224-241

Du, S., Edward, dan Vieira, 2012. Striving for legitimacy through corporate social responsibility: insighs from oil companies, [ejournal] 110(3). Tersedia melalui: ProQuest <http://www.proquest.com/> [Diakses pada 18 September 2018].

Global Reporting Initiative, 2011. Sustainability reporting guidelines version 3.1. Amsterdam: Global Reporting Initiative [online] Tersedia melalui: http://www.globalreporting.org/, Diakses pada 30 Oktober 2018.

Gray, R., Owen, D. and Adams, C. (1996), Accounting and Accountability: Changes and Challenges in Corporate Social and Environmental Reporting, Prentice Hall Europe, Hemel Hempstead.

Laporan Keberlanjutan (Sustainability Report).2017.Inspirasi 60 tahun Astra. www.astra.co.id diakses tanggal 30 Oktober 2018

McWilliams, A \& Siegel, D. 2001. Corporate Social Responsibility: A Theory of the Firm perspective. Academy of Management Review, 26 (1), 117-127

Nwagbara, U., dan Reid, P., 2013. Corporate social responsibility communication in the age of new media: towards the logic of sustainability communication, [e-journal] 14(3). Tersedia melalui: ProQuest $<$ http://www.proquest.com/ $>$ [Diakses pada 14 Maret 2014].

Parker, C., Zutshi, A., dan Fraunholz, B. 2010, 'Online Corporate Social Responsibility Communication by Australian SMEs: A Framework for Website Analysis'. 23rd Bled eConference eTrust: implication for the individual, enterprises and society, 20-23 Juni 2010, Bled. s.l: s.n

Semendanta Pusaka. 2017. Peluncuran GRI Standards 2018: Membaa Arah Akuntabilitas Masa Depan. 12 Juni 2017, http://majalahcsr.id/peluncuran-gri-standards-2018-membaca-arah-akuntabilitas-masa-depan/3/. Diakses tanggal 27 Oktober 2018. 